\title{
SIMULASI SISTEM PENGHITUNG JUMLAH MOBIL KELUAR DAN PENGHITUNGAN TARIFNYA BERDASARKAN LAMA WAKTU PADA GEDUNG PARKIR MOBIL BERLANTAI TIGA BERBASIS MIKROKONTROLER ATMEGA 8535
}

\author{
Ruky Sandra Ary M, Saiful Manan \\ Program Studi Diploma III Teknik Elektro \\ Fakultas Teknik Universitas Diponegoro
}

\begin{abstract}
Ruky Sandra Ary M, Saiful Manan, in this paper explain that parking lot which is widely used today do not present an empty parking location data, causing the vehicle entering the parking area must first find an empty parking space. This led to queues of vehicles becomes unavoidable. Even vehicles must berputarputar first to find an empty parking space. Therefore, it needs a parking system that can alert parking block capacity is still empty. Parking tariff determination system also plays an important role, most of the park determines the rate only on the type of vehicle rather than on how much time parking felt unjust for some people. This study designed a microcontroller-based parking system that can determine the number of cars remaining at the same time counting parking rates is a unified tool that can be divided into two, namely, hardware and software as a mechanical system that will work as a control system and the process of calculating tariffs.
\end{abstract}

Keywords: parking system, Microcontroller 8535, Infrared, parking rates, Password

\section{PENDAHULUAN}

Dengan banyaknya jumlah kendaraan karena ketergantungan manusia pada sarana transportasi khususnya kendaraan pribadi semakin bertambah besar untuk menunjang kegiatan sehari-hari, tentunya membutuhkan tempat parkir yang bertambah luas terutama pada pertokoan/mal, perkantoran dan pusat-pusat keramaian lainnya. Permasalahan yang biasanya terjadi adalah tidak mengetahuinya pengemudi akan lokasi parkir yang masih tersisa (kosong), sehingga menyebabkan kendaraan yang akan masuk tempat parkir harus berputar-putar dahulu untuk mencari lokasi yang masih kosong. Belum adanya sistem parkir yang menyajikan data lokasi yang kosong pada kebanyakan tempat parkir membuat keadaan ini kurang nyaman karena sangat membingungkan dan memakan waktu yang lama.

Dengan perkembangan dan kemajuan ilmu pengetahuan dan teknologi khususnya dalam bidang elektronika yang memegang peranan sangat penting. Rangkaian mikrokontroler ATmega 8535 merupakan rangkaian yang bekerja jika pada memori flashnya diberi program aplikasi sesuai ketentuan yang ada, atau juga dapat dihubungkan langsung ke personal komputer dengan sistem ISP yang dimiliki oleh mikrokontroler ATmega 8535.

\section{LANDASAN TEORI}

\section{Resistor}

Resistor adalah suatu komponen elektronika yang fungsinya untuk menghambat arus listrik. Nilai resistansi (hambatan) pada sebuah resistor dinyatakan dengan satuan Ohm yang dilambangkan dengan symbol $\Omega$.

\section{Kapasitor}

Kapasitor adalah suatu komponen elektronika yang dapat menyimpan dan melepaskan muatan listrik atau energi listrik. Kemampuan untuk menyimpan muatan listrik disebut dengan kapasitansi, yang dilambangkan dengan huruf $\mathrm{C}$ dan dinyatakan dengan satuan farad (f).

Sebuah kapasitor terbuat dari dua buah plat metal yang dipisahkan oleh suatu bahan dielektrik. Bahan-bahan dielektrik yang umum digunakan misalnya udara vakum, keramik, gelas, mika, kertas dan lain-lain.

\section{Dioda}

Dioda merupakan sebuah komponen elektronika yang berfungsi sebagai penyearah. Hal ini terjadi karena pada sebuah dioda mengalami dua siklus yaitu bias maju dan bias mundur. Pada saat bias maju arus yang mengalir ke dioda akan diteruskan dan dapat melewati dioda, sedangkan pada saat bias mundur dioda akan menahan arus dari arah berlawanan yang menuju ke dioda.

Dioda termasuk komponen elektronika yang terbuat dari bahan semikonduktor, yang merupakan persambungan antara semikonduktor P dan N. Satu sisi adalah semikonduktor dengan tipe $\mathrm{P}$ dan satu sisinya yang lain adalah tipe $N$. Dengan struktur demikian arus hanya akan dapat mengalir dari sisi P menuju sisi N.

\section{Transistor}

Transistor adalah piranti elektronik yang menggantikan fungsi tabung elektron-trioda, dimana transistor ini mempunyai tiga elektroda, yaitu Emitter, Collector dan Base. Fungsi utama atau tujuan utama pembuatan transistor adalah 
sebagai penguat (amplifier), namun dikarenakan sifatnya, transistor ini dapat digunakan dalam keperluan lain misalnya sebagai suatu saklar elektronis. Susunan fisik transistor adalah merupakan gandengan dari bahan semikonduktor tipe $\mathrm{P}$ dan $\mathrm{N}$.

\section{Tranformator}

Transformator atau transformer atau trafo adalah komponen elektromagnet yang dapat mengubah taraf suatu tegangan AC ke taraf yang lain.

Transformator terdiri dari 3 komponen pokok yaitu: kumparan pertama (primer) yang bertindak sebagai input, kumparan kedua (skunder) yang bertindak sebagai output, dan inti besi yang berfungsi untuk memperkuat medan magnet yang dihasilkan.

\section{Catu Daya}

Catu daya berfungsi sebagai penyearah tegangan (juga arus) listrik bolak-balik menjadi tegangan (juga arus) listrik searah.

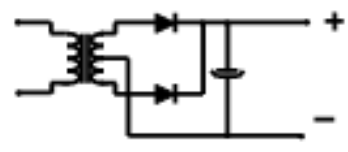

Gambar 1. Catu daya

\section{Infra Merah}

Beberapa ragam indicator status LED yang tampak (Visible) adalah merah, hijau, kuning. Selain itu juga terdapat LED dengan cahaya yang tidak tampak (Invisible) seperti LED infra merah. Infra merah adalah sinar dengan panjang gelombang $(\lambda)$ lebih besar dari $800 \mathrm{~nm}$ dan tidak dapat dilihat oleh mata.

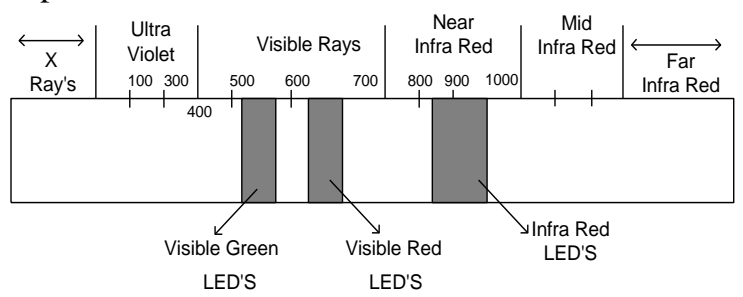

Gambar 2. Spektrum sinar

\section{LCD}

LCD merupakan modul tampilan kristal cair matriks titik dengan pengendali didalamnya. LCD display terdiri dari dua bagian, yang pertama merupakan panel LCD sebagai media penampil informasi dalam bentuk huruf/angka.

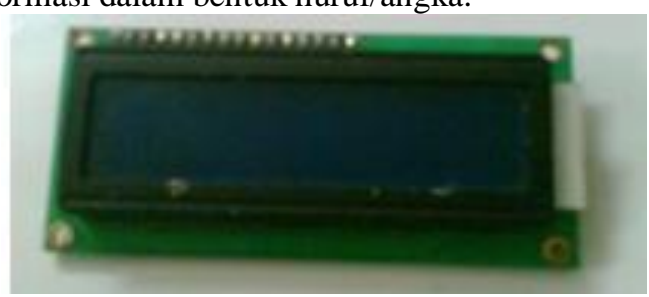

Gambar 3.LCD

\section{Mikrokontroler ATMega 8535}

Mikrokontroler AVR menggunakan teknologi RISC dimana set instruksinya dikurangi dari segi ukurannya dan kompleksitas mode pengalamatannya. Pada awal era industri komputer, bahasa pemrograman masih menggunakan kode mesin dan bahasa assembly. Untuk mempermudah dalam pemrograman para desainer komputer kemudian mengembangkan bahasa pemrograman tingkat tinggi yang mudah dipahami manusia. Namun akibatnya, instruksi yang ada menjadi semakin komplek dan membutuhkan lebih banyak memori. Dan tentu saja siklus eksekusi instruksinya menjadi semakin lama. Dalam AVR dengan arsitektur RISC 8 bit, semua instruksi berukuran 16 bit dan sebagian besar dieksekusi dalam 1 siklus clock. Berbeda dengan mikrokontroler MCS-51 yang instruksinya bervariasi antara 8 bit sampai 32 bit dan dieksekusi selama 1 sampai 4 siklus mesin, dimana 1 siklus mesin membutuhkan 12 periode clock.

Dalam perkembangannya, AVR dibagi menjadi beberapa varian yaitu AT90Sxx, ATMega, AT86RFxx dan ATTiny. Pada dasarnya yang membedakan masing-masing varian adalah kapasitas memori dan beberapa fitur tambahan saja.

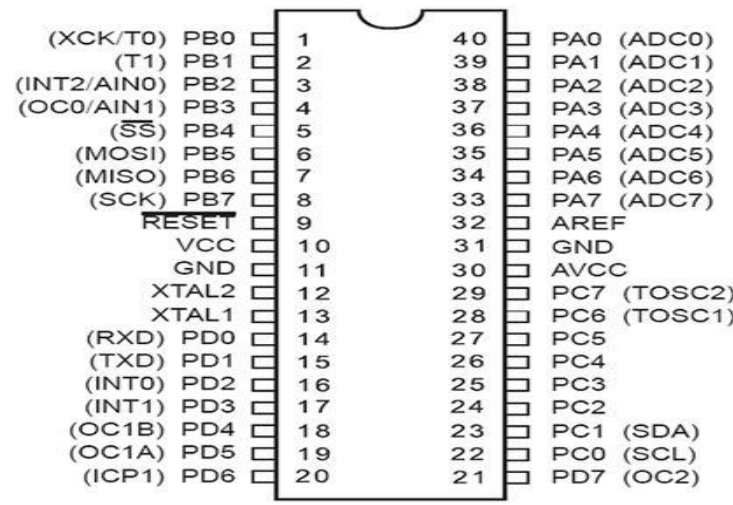

Gambar 4. Konfiggurasi ATMega 8535

\section{Motor DC}

Motor arus searah adalah suatu mesin yang berfungsi mengubah tenaga listrik arus searah (DC) menjadi tenaga gerak atau putaran dimana tenaga gerak tersebut berupa putaran rotor. Arah gerak kawat itu dapat ditentukan dengan "kaidah tangan kiri" yang berbunyi sebagai berikut: "Apabila tangan kiri terbuka diletakkan diantara kutub U dan $\mathrm{S}$, sehingga garis-garis gaya yang keluar dari kutub utara menembus telapak tangan kiri dan arus di dalam kawat mengalir searah dengan arah keempat jari, maka kawat itu akan mendapat gaya yang arahnya sesuai dengan arah ibu jari”. 


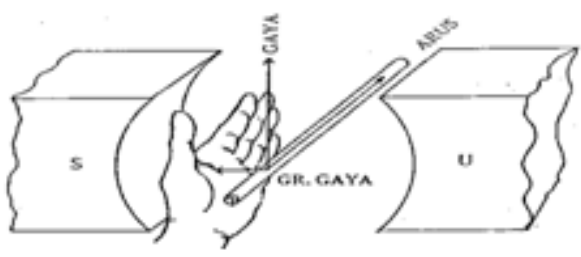

Gambar 5. Kaidah Tangan Kiri

\section{Bahasa Pemrograman}

Bahasa pemrograman, atau sering diistilahkan juga dengan bahasa komputer, adalah teknik komando/instruksi standar untuk memerintah komputer. Bahasa pemrograman ini merupakan suatu set aturan sintaks dan semantik yang dipakai untuk mendefinisikan program komputer. Bahasa ini memungkinkan seorang programmer dapat menentukan secara persis data mana yang akan diolah oleh komputer, bagaimana data ini akan disimpan/diteruskan, dan jenis langkah apa secara persis yang akan diambil dalam berbagai situasi.

\section{SIMULASI SISTEM}

\section{Cara Kerja Sistem}

Pada Simulasi Sistem Penghitung Jumlah Mobil Keluar Dan Penghitungan Tarifnya Berdasarkan Lama Waktu Pada Gedung Parkir Mobil Berlantai Tiga Berbasis Mikrokontroler ATMega 8535 ini merupakan sebuah kesatuan alat yang dapat dibagi menjadi dua, yaitu rangkaian hardware sebagai sistem mekanik dan software yang akan bekerja sebagai sistem kontrol dan proses penghitungan tarif.

Rangkaian hardware terdiri dari catu daya, sensor, driver motor sebagai penggerak motor dc, LCD, dan Mikrokontroller ATMega 8535. Sedangkan software yang digunakan pada sistem ini ada dua, yaitu CodeVision AVR untuk mengubah pemrograman Bahasa $\mathrm{C}$ sehingga dapat dimengerti oleh mikrokontroler dan Borland Delphi sebagai program penghitungan tarif parkirnya.

Untuk penjelasan lebih lanjut, akan dibahas cara kerja rangkaian keseluruhan dan cara kerja rangkaian tiap blok.

\section{Cara Kerja Keseluruhan}

Pada alat ini terdapat tiga buah lantai sebagai tempat parkir, dimana pada masing-masing lantainya terdapat sebuah sensor infra merah pada pintu kelur yang digunakan sebagai sensor pengurang jumlah mobil. Bila mobil akan meninggalkan tempat pakir, maka sensor infra merah ini akan terpotong sehingga memberikan inputan kepada Mikrokontroller untuk mengolah data yang nantinya akan memberikan outputan pada tampilan LCD. Bila sudah berada di loket parkir pengguna akan memasukkan password yang sama pada saat dia masuk tadi, tujuannya adalah sebagai sistem penghitungan tarif parkir dan juga sebagai faktor keamanan. Saat password yang ditekan sama akan muncul tampilan jumlah tarif yang dikenakan pada monitor dan Mikrokontroller akan membuka portal pintu keluar. Setelah portal membuka mobil akan menuju keluar area tempat parkir, untuk menutup kembali portal pintu keluar terdapat sebuah sensor infra merah pada jalan keluar tempat parkir tersebut. Mikrokontroler akan mengolah inputan sensor penutup portal sesuai program yang sudah ada di memori flashnya berupa outputan pada driver motor dc yang nantinya akan menggerakkan motor dc untuk menutup portal.

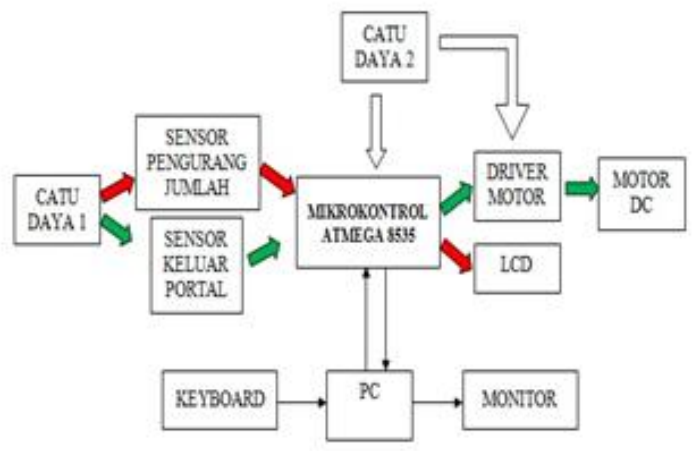

Gambar 6. Diagran Blok

\section{Cara Kerja Rangkaian Tiap Blok \\ Catu Daya}

Sumber tegangan yang berupa tegangan AC $220 \mathrm{~V}$ diturunkan oleh transformator step down sehingga dihasilkan tegangan AC yang lebih rendah, yaitu sebesar 12 volt. Selanjutnya, output dari sisi sekunder transformator disearahkan oleh dioda rectifier, sehingga dihasilkan ouput DC, namun masih kasar. Kapasitor $3300 \mu \mathrm{F} / 50 \mathrm{~V}$ digunakan sebagai filter untuk meratakan keluaran dari dioda serta untuk mengurangi tegangan ripple. Dengan menggunakan kapasitor, sinyal-sinyal AC yang masih terbawa akan ditanahkan, sedangkan sinyal DC akan diteruskan ke IC regulator LM 7812 dan LM 7805. IC regulator LM 7812 digunakan untuk menghasilkan tegangan sebesar 12 volt dan LM 7805 digunakan untuk menghasilkan tegangan sebesar 5 volt. Selain sebagai regulator, IC LM 7812 dan LM 7805 juga digunakan sebagai penstabil tegangan, sehingga tegangan keluaran menjadi stabil dan sesuai dengan besar tegangan yang diinginkan, yaitu sebesar 12 volt dan 5 volt.

\section{Sensor Infra Merah}

Rangkaian sensor infra merah menggunakan foto dioda dan led infra merah yang dihubungkan secara optik. Foto dioda akan aktif apabila terkena cahaya dari led infra merah. Antara Led dan foto transistor dipisahkan oleh jarak. Jauh dekatnya jarak mempengaruhi besar intensitas cahaya yang diterima oleh foto dioda. Apabila antara Led dan foto dioda tidak terhalang oleh benda, maka foto dioda akan aktif. Untuk keperluan penambahan jumalh digunakan untuk mendeteksi adanya gerakan mobil di suatu ruangan atau area, sehingga 
jika sensor terhalang oleh mobil, maka akan mendeteksi kehadiran mobil di dalam ruangan tersebut kemudian mikrokontroler akan mengeksekusi perintah tersebut yang kemudian memerintahkan LCD untuk merubah tampilan dari sebelumnya.

\section{Mikrokontroler ATMega 8535}

Rangkaian mikrokontroler ATmega 8535 merupakan rangkaian yang bekerja jika pada memori flashnya diberi program aplikasi sesuai ketentuan yang ada, atau juga dapat dihubungkan langsung ke personal komputer dengan sistem ISP yang dimiliki oleh mikrokontroler ATmega 8535.

Adapun pembagian port pada aplikasi modul mikrokontroler AT mega 8535 adalah sebagai berikut:

- Port C digunakan untuk menghubungkan mikrokontroler ATMega 8535 dengan LCD.

- Port B digunakan untuk menghubungkan mikrokontroler ATMega 8535 dengan Keypad.

- Port D2 digunakan untuk menghubungkan mikrokontroler ATMega 8535 dengan sensor masuk lantai 1.

- Port D4 digunakan untuk menghubungkan mikrokontroler ATMega 8535 dengan sensor masuk lantai 2.

- Port D6 digunakan untuk menghubungkan mikrokontroler ATMega 8535 dengan sensor masuk lantai 3.

- Port D3 digunakan untuk menghubungkan mikrokontroler ATMega 8535 dengan sensor keluar lantai 1.

- Port D5 digunakan untuk menghubungkan mikrokontroler ATMega 8535 dengan sensor keluar lantai 2.

- Port D7 digunakan untuk menghubungkan mikrokontroler ATMega 8535 dengan sensor keluar lantai 3.

- Port A0 digunakan untuk menghubungkan mikrokontroler ATMega 8535 dengan sensor pintu masuk (limit switch).

- Port A1 dan A2 digunakan untuk menghubungkan mikrokontroler ATMega 8535 dengan motor pintu masuk.

- Port A6 digunakan untuk menghubungkan mikrokontroler ATMega 8535 dengan sensor mobil pada pintu masuk.

- Port A3 digunakan untuk menghubungkan mikrokontroler ATMega 8535 dengan sensor pintu keluar (limit switch).

- Port A4 dan A5 digunakan untuk menghubungkan mikrokontroler ATMega 8535 dengan motor pintu keluar.

\section{LCD}

Tampilan LCD yang dipakai pada sistem ini adalah tampilan LCD jenis dot matrix yang memiliki 2 x 16 karakter. Angka 2 menunjukkan banyaknya baris pada tampilan LCD dan angka enambelas menunjukkan banyaknya kolom pada tampilan LCD. Dengan demikian LCD dot matrix yang dipakai oleh sistem ini mampu menampilkan karakter sebanyak 32 karakter.

LCD dot matrix ini membutuhkan 7 pin masukan atau keluaran pada mikrokontroler ATMega8535. Jalur ini merupakan jalur data bus 2 arah. Jalur ini dibagi menjadi 2 yaitu: 4 bit rendah (DB0-DB3) dan 4 bit tinggi (DB4-DB7). Jika LCD ini dihubungkan dengan mikokontroler 4 bit maka jalur 4 bit terendah tidak digunakan. Ketujuh pin tersebut digunakan untuk menampilkan karakter yang dikehendaki. Tiga pin masukan atau keluaran digunakan untuk mengendalikan proses pengiriman data ke LCD, dan jalur E digunakan untuk jalur masukan yang berfungsi untuk mengaktifkan dan tidak mengaktifkan LCD. Jalur R/W merupakan jalur masukan. Jika diset ' 0 ' digunakan untuk menulis data ke LCD dan jika diset ' 1 ' akan membaca dari LCD. Jalur RS merupakan jalur masukan 2 pilihan yaitu '0': Intruksi register (Write), Busy Flag dan Address counter (Read), dan '1': Data register (Write dan Read).

Pin Vcc pada LCD dihubungkan ke suplai + Vcc dan pin Vss dihubungkan ke ground. Pin $\mathrm{V}_{\mathrm{EE}}$ beserta pin Vcc dan Vss dihubungkan ke trimer potensio atau disebut trimpot. Trimpot ini digunakan untuk mengatur kontras tampilan LCD dengan cara mengubah tegangan pada pin $\mathrm{V}_{\mathrm{EE}}$.

\section{MOTOR DC}

Motor dc yang digunakan sebagai penggerak portal ini mendapat tegangan sebesar $12 \mathrm{~V}$ dari catu daya untuk mensupply relay dan motor, sedangkan tegangan $5 \mathrm{~V}$ dan output Mikrokontroller digunakan sebagai inputan pada driver motor dc. Terdapat dua kondisi yang terjadi yaitu putar kanan sehingga portal membuka dan putar kiri sehingga motor menutup.

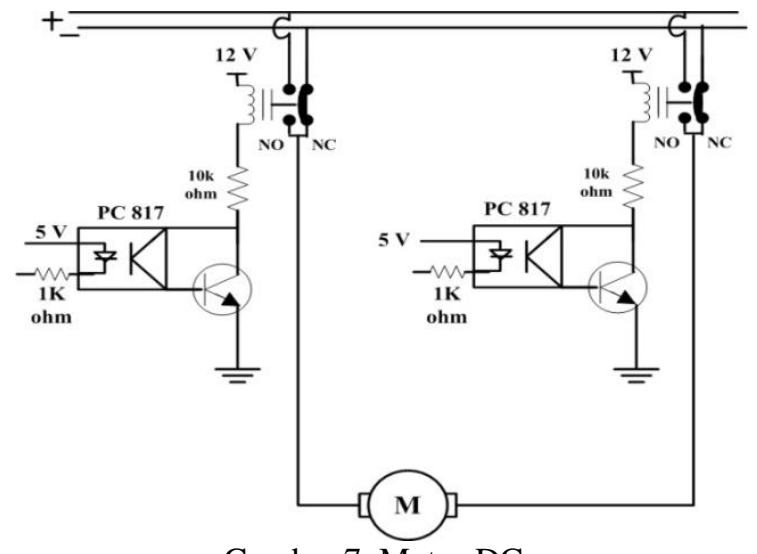

Gambar 7. Motor DC

Kondisi pertama, motor putar kanan. Optocoupler pc 817 akan aktif jika mendapat logika 0 dari input mikrokontroler pada Pin A4, karena tegangan mengalir dari input $5 \mathrm{~V}$ yang mendapat 
logika 1. Pc 817 yang aktif menyebabkan driver motor dc juga aktif, hal ini mengakibatkan tegangan $12 \mathrm{~V}$ dari catu daya yang mensuply relay mengalir ke ground sehingga mengaktifkan relay, posisi awal relay yang semula Normally Close (NC) menjadi Normally Open (NO). Kondisi sebaliknya terjadi pada optocoupler dua yang tidak aktif karena input mikro Pin A5 mendapat logika 1 sehingga arus tidak bisa mengalir, karena pc 817 tidak aktif maka driver motor dc juga tidak aktif sehingga menyebabkan relay berada pada posisi tetap yaitu Normally Close(NC). Pada kondisi ini menyebabkan portal membuka.

Kondisi kedua, motor putar kiri. Kondisi ini merupakan kebalikan dari kondisi pertama, dimana optocoupler satu mendapat logika 1 sehingga driver motor tidak aktif yang menyebabkan relay berada pada posisi tetap (NC). Bila optocoupler satu berlogika 1 maka optocoupler dua mendapat logika 0 sehingga aktif dan mengalirkan tegangan pada driver motor, driver motor yang aktif menyebabkan relay juga menjadi aktif sehingga menarik posisi relay yang semula Normally Close (NC) menjadi Normally Open (NO). Kondisi ini menyebabkan portal menutup.

\section{CODE VISION AVR}

Perancangan perangkat lunak disini dimaksudkan untuk memprogram mikrokontroler agar bekerja sesuai keinginan. Dengan memanfaatkan compiler CodeVision AVR, hasil buatan HP InfoTech, untuk mengubah bahasa pemrograman $\mathrm{C}$ menjadi bahasa assembler (rakitan), sehingga dapat dimengerti oleh mikrokontroler. Dalam hal ini digunakan bahasa pemrograman $\mathrm{C}$ untuk memprogram mikrokontroler adalah karena jika dibandingkan dengan bahasa rakitan (assembler), $\mathrm{C}$ merupakan bahasa pemrograman yang relatif lebih mudah dalam pembuatan dan pengembangan suatu aplikasi. Demikian pula saat tracing program untuk mencari kesalahan dalam penulisan perintah.

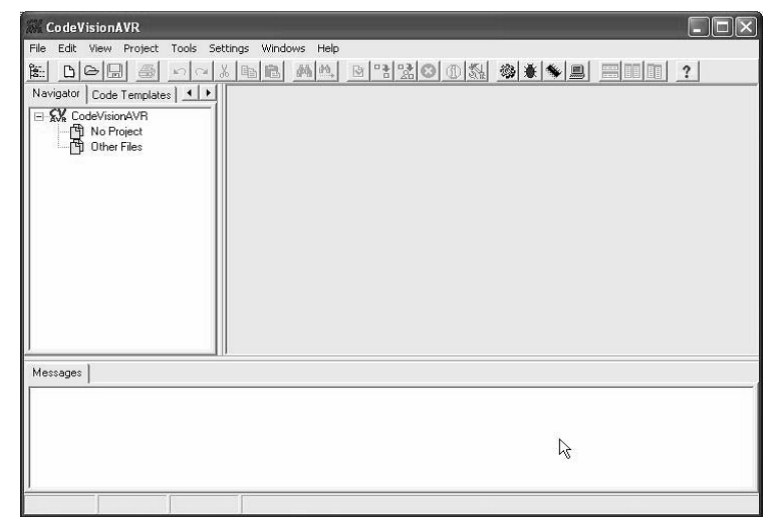

Gambar 8. Tampilan CodeVision AVR

\section{BORLAND DELPHI}

Program interface dengan komputer bisa dilakukan dengan banyak cara salah satunya secara serial. Transfer data secara serial berarti juga data dikirim dari devais luar misalnya mikrokontroller ke komputer secara serial dengan standard yang telah ditentukan. Data dikirim per 8 bit dengan bit star dan bit stop bisa juga ditambahkan parity. Pada tulisan kali ini akan dibahas bagaimana membuat program interface serial menggunakan delphi.

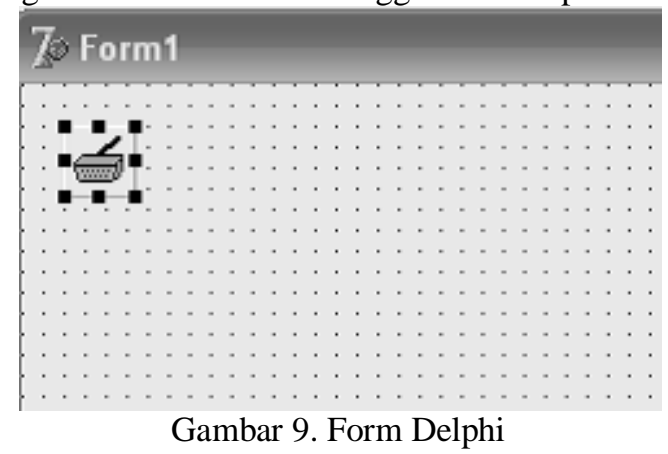

\section{PEMBUATAN ALAT}

Pembuatan Bagian Mekanik (Maket)

Pembuatan bagian mekanik meliputi pembuatan loket, gedung, dan landasan. Hal ini bertujuan agar dalam perakitan antarmodul tidak terdapat sambungan kabel yang berada di luar maket, sehingga benda kerja yang dibuat tampak rapi dan lebih ringkas. Adapun tahap-tahap yang dikerjakan dalam pembuatan maket ini antara lain sebgaai berikut:

- Mengukur dan memotong papan untuk maket sesuai dengan ukuran yang telah direncanakan

- Pengeboran, yaitu dengan menggunakan mata bor besi yang ukurannya disesuaikan dengan ukuran lubang yang akan dibuat. Sebelum dibor, papan sebelumnya diberi tanda terlebih dulu dengan penitik/pensil pada bagian yang perlu diberi lubang untuk pemasangan sekrup/spacer untuk penempatan blok PCB.

- Perakitan potongan papan maket.

- Pemasangan/perakitan rangkaian pada maket, yaitu dilakukan dengan menyekrup bagian tepi PCB. Pemasangan rangkaian harus diatur sedemikian rupa sehingga papan rangkaian tidak mengganggu komponen lain, jika perlu dipasangkan spacer pada papan rangkaian.

Spesifikasi dan ukuran alat dapat dilihat pada gambar 10 dan 11 .

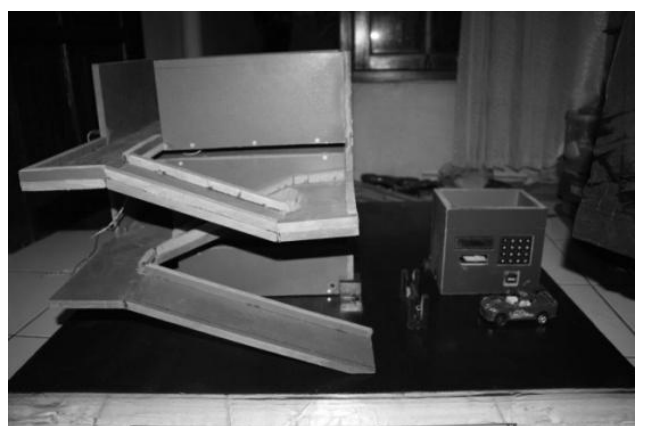

Gambar 10. Maket keseluruhan (tampak sampig) 


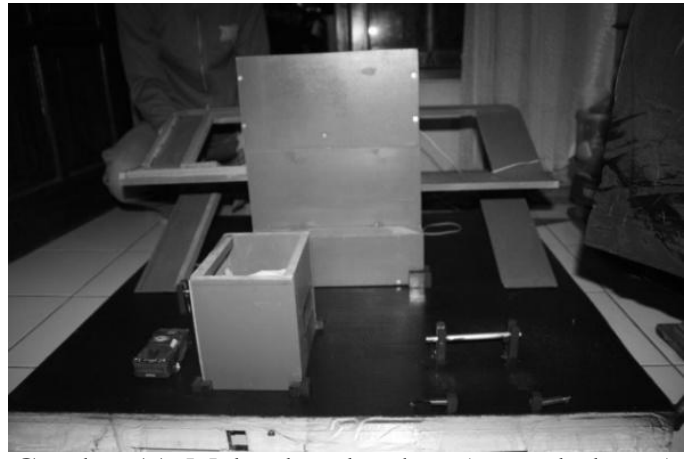

Gambar 11. Maket keseluruhan (tampak depan)

Rangkian yang telah selesai dirakit dan teruji dipasang pada bawah maket. Pemasangan modul rangkaian pada kotak rangkaian ini dilakukan dengan memberi skrup bagian tepi dari modul. Untuk menghindari terjadinya hubung singkat antara modul dan kotak maka pada modul perlu dilapisi dengan isolasi penyekat. Pada saat pemasangan rangkaian, posisi modul harus diatur sedemikian rupa sehingga papan rangkaian yang terpasang tidak mengganggu komponen lainnya seperti sakelar dan terminal. Disamping itu, kabelkabel penghubung serta komponen pelengkap lainnya diatur sedemikian rupa sehingga segi keindahan dan kerapiannya tetap terjaga.

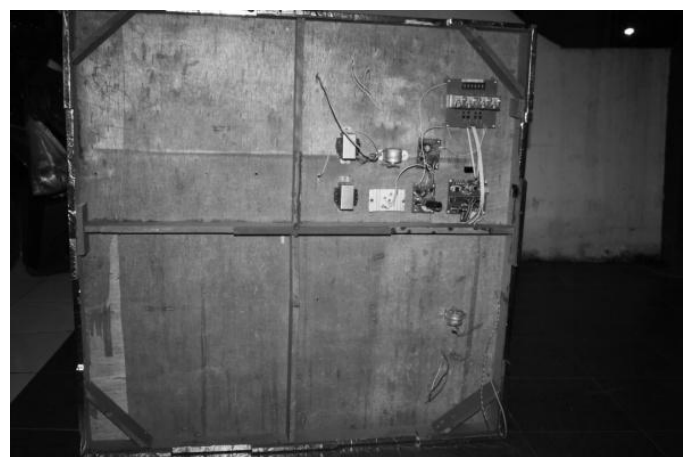

Gambar 12. Maket keseluruhan (bawah)

Untuk ukuran maket, dapat dilihat pada data dibawah ini (panjang $x$ lebar x tinggi) :

Panjang : $91 \mathrm{~cm} \mathrm{x} 7 \mathrm{~cm} \times 89 \mathrm{~cm}$

Gedung : $45 \mathrm{~cm} \times 43 \mathrm{~cm} \times 82 \mathrm{~cm}$

Loket $\quad: 18 \mathrm{~cm} \times 13,5 \mathrm{~cm} \mathrm{x} 16,5 \mathrm{~cm}$

\section{Pembuatan Diagram Alir}

Dalam menyusun diagram alir diusahakan dapat membagi proses yang kompleks menjadi sub program yang lebih kecil, sehingga pencarian kesalahan akan lebih mudah. Selain itu akan memudahkan orang lain dalam membaca alir program yang dibuat.

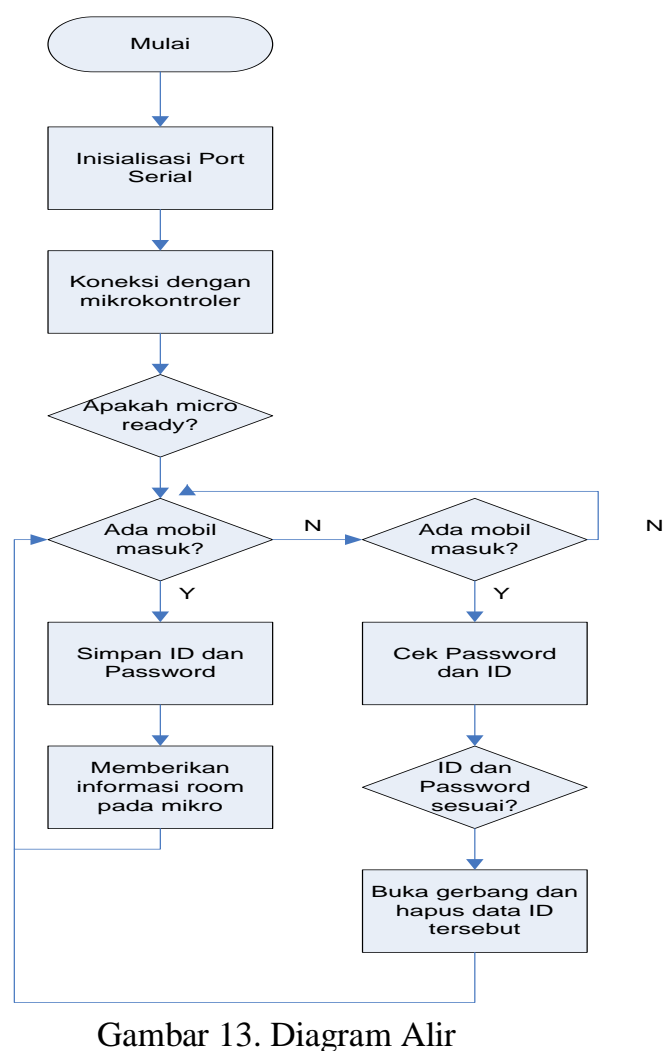

\section{Pembuatan Program}

Penulisan program dilaksanakan setelah diagram alir selesai dirancang. Pada pembuatan program mikrokontroler, memerlukan suatu sistem program untuk menempatkan dan mengirim program dari PC ke mikrokontroler. Sistem program pendukung yang digunakan pada modul ini adalah CodeVision AVR dan Borland Delphie.

\section{Pengisian Program}

Perlengkapan yang dibutuhkan dalam pengisian flash ATmega 8535:

- Catu Daya 12 V.

- $\quad$ PC dengan sistem operasi Microsoft Windows 9X / ME / NT / 2000.

- Penulisan program dilakukan dengan menggunakan program pendukung CV AVR

- 4. Kabel ISP untuk komunikasi antara PC dengan mikrokontroler ATmega 8535.

Pengisian program yang telah dikompilasi dalam format heksadesimal (hex), diisikan ke dalam mikrokontroler ATmega 8535 menggunakan kabel ISP sebagai pengisi Flash EPROM mikrokontroler ATmega 8535 dengan menjalankan perangkat lunak pemrograman.

Urutan cara pengisian program ke dalam Flash EPROM ATmega 8535 adalah sebagai berikut :

- Pasang IC ATmega 8535 pada soket yang telah ditentukan pada rangkaian pengisi Flash EPROM Programmer mode Serial ATmega 8535 . 
- Pastikan kabel ISP antara PC dengan rangkaian programmer ATmega 8535 telah terpasang.

- Berikan catu tegangan DC $12 \mathrm{~V}$ ke rangkaian sistem minimum.

- Buka file yang akan didownload, lakukan kompilasi listing program.

- Mendownload file hex hasil kompilasi dengan program chip programmer.

- Alat siap dijalankan.

\section{PENGUKURAN DAN PENGUJIAN ALAT \\ Cara Pengukuran}

Pengukuran dilakukan dengan metode pengukuran tegangan. Titik-titik pengukuran ditentukan dengan mempertimbangkan pengaruh yang terjadi jika tegangan pada titik tersebut tidak sesuai dengan harga yang semestinya.

\section{Alat dan Bahan yang Digunakan}

- Catu daya 5V,12V : 1 buah

- Multimeter : 1 buah

- Kabel penghubung : secukupnya

\section{Langkah Pengukuran}

- Mempersiapkan tata letak komponen pada rangkaian yang akan diukur.

- Mempersiapkan peralatan yang akan digunakan.

- Menentukan titik-titik pengukuran.

- Mencatat hasil yang telah diperoleh dalam pengukuran.

\section{Rangkaian Catu Daya}

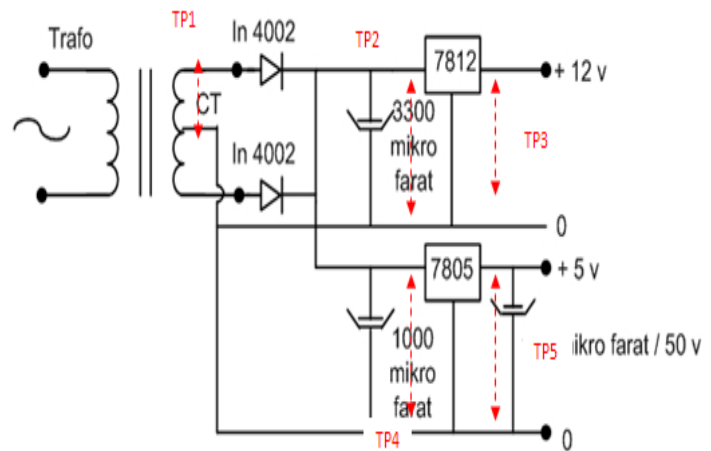

Gambar 14. Titik Pengukuran catu daya

Tabel 1. Hasil pengukuran catu daya

\begin{tabular}{ccc}
\hline \multicolumn{2}{c}{ Titik Pengukuran } & Tegangan \\
\hline $\mathrm{TP}_{1}$ & Output trafo & 11,9 Volt \\
$\mathrm{TP}_{2}$ & Input LM7812 & 14,8 Volt \\
$\mathrm{TP}_{3}$ & Output LM7812 & 11,9 Volt \\
$\mathrm{TP}_{4}$ & Input LM7805 & 11,9 Volt \\
$\mathrm{TP}_{5}$ & Output LM7805 & 4,9 Volt \\
\hline
\end{tabular}

\section{Rangkaian Sensor}

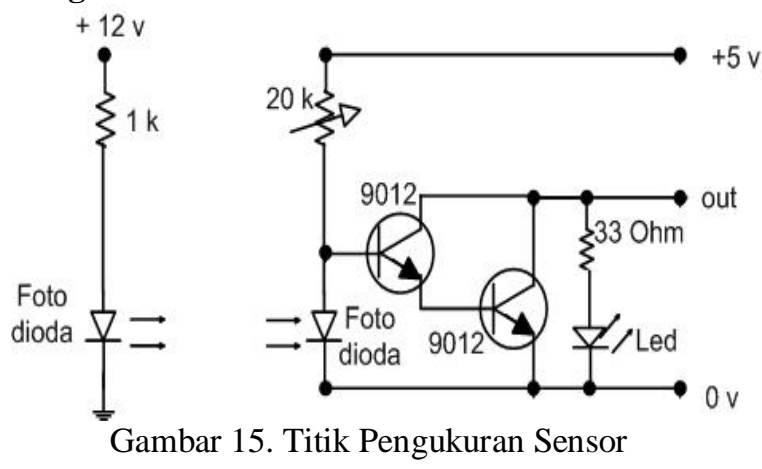

Tabel 2. Hasil pengukuran sensor

\begin{tabular}{cc}
\hline Foto Dioda & Out \\
\hline Tidak terhalang & $0,489 \mathrm{v}$ \\
Terhalang & $4,899 \mathrm{v}$ \\
\hline
\end{tabular}

Rangkaian Motor DC

Tabel 3. Hasil pengukuran Motor DC

\begin{tabular}{cc}
\hline Pengukuran & Tegangan (Dc Volt) \\
\hline Pin Vs & 7,5 \\
Pin Vss / Vcc & 5,8 \\
Motor DC putar kiri & 11,8 \\
Motor DC putar & 11,8 \\
kanan & \\
\hline
\end{tabular}

LCD

Tabel 4. Hasil pengukuran LCD

\begin{tabular}{ccc}
\hline Pin LCD & $\begin{array}{c}\text { Tegangan } \\
(\mathbf{V})\end{array}$ & Keterangan \\
\hline 1 & 0 & Vss \\
2 & 4.8 & Vcc \\
3 & 0.2 & VLC \\
4 & 4.9 & RS \\
5 & 0.02 & R/W \\
6 & 1.55 & E \\
7 & - & DB0 \\
8 & - & DB1 \\
9 & - & DB2 \\
10 & - & DB3 \\
11 & 0.05 & DB4 \\
12 & 0.1 & DB5 \\
13 & 0.09 & DB6 \\
14 & 0,04 & DB7 \\
15 & 4,9 & V+ \\
16 & 0,22 & V- \\
\hline
\end{tabular}


Tabel 5. Percobaan Lantai 1

\begin{tabular}{cccc}
\hline Percobaan & $\begin{array}{c}\text { Mobil } \\
\text { Keluar }\end{array}$ & $\begin{array}{c}\text { Sensor } \\
\text { Mendeteksi }\end{array}$ & $\begin{array}{c}\text { Tampilan } \\
\text { LCD }\end{array}$ \\
\hline 1 & - & - & FULL \\
2 & v & v & 49 \\
3 & v & v & 48 \\
4 & v & v & 47 \\
$\cdot$ & $\cdot$ & $\cdot$ & $\cdot$ \\
. & $\cdot$ & $\cdot$ &. \\
50 & v & v & 00 \\
\hline
\end{tabular}

Tabel 6. Percobaan Lantai 2

\begin{tabular}{cccc}
\hline Percobaan & $\begin{array}{c}\text { Mobil } \\
\text { Keluar }\end{array}$ & $\begin{array}{c}\text { Sensor } \\
\text { Mendeteksi }\end{array}$ & $\begin{array}{c}\text { Tampilan } \\
\text { Lcd }\end{array}$ \\
\hline 1 & - & - & FULL \\
2 & v & v & 49 \\
3 & V & v & 48 \\
4 & v & v & 47 \\
$\cdot$ & $\cdot$ & $\cdot$ & $\cdot$ \\
$\cdot$ & $\cdot$ & $\cdot$ & $\cdot$ \\
. & $\cdot$ & $\cdot$ &. \\
50 & v & v & 00 \\
\hline
\end{tabular}

Tabel 7. Lantai 3

\begin{tabular}{cccc}
\hline Percobaan & $\begin{array}{c}\text { Mobil } \\
\text { Keluar }\end{array}$ & $\begin{array}{c}\text { Sensor } \\
\text { Mendeteksi }\end{array}$ & $\begin{array}{c}\text { Tampilan } \\
\text { Lcd }\end{array}$ \\
\hline 1 & - & - & FULL \\
2 & v & v & 49 \\
3 & v & v & 48 \\
4 & v & v & 47 \\
. &. & $\cdot$ & $\cdot$ \\
. &. & $\cdot$ &. \\
50 & v & v & 00 \\
\hline
\end{tabular}

\section{KESIMPULAN}

Setelah melakukan perancangan, pembuatan benda kerja, dan pengujian alat, maka dapat disimpulkan

- Simulasi sistem ini menggunakan pemrograman Bahasa $\mathrm{C}$ dan dengan memanfaatkan compiler CodeVision AVR, hasil buatan HP InfoTech, untuk mengubah pemrograman Bahasa $\mathrm{C}$ menjadi bahasa assembler (rakitan), sehingga dapat dimengerti oleh mikrokontroler.

- $\quad 3$ buah sensor infra merah digunakan sebagai pendeteksi mobil keluar di tiap lantai dan 1 buah sebagai penutup portal pada saat keluar.
- Proses penghitungan tarif dimulai saat pengguna menekan password melalui keypad dan berhenti saat memasukkan password yang sama pada saat keluar.

- Borland delphi digunakan sebagai tampilan tarif parkir.

- Penentuan tarif parkir pada simulasi sistem ini berdasarkan menit dengan kelipatan Rp 40,00 tiap menitnya.

\section{DAFTAR PUSTAKA}

1. Barwami, Malvino. 1985. Prinsip - Prinsip Elektronika Jilid 1. Jakarta : Erlangga

2. Barwami, Malvino. 1985. Prinsip - Prinsip Elektronika Jilid 2. Jakarta : Erlangga

3. Datasheet ATMega8535. www.atmel.com kamis 15 juli 2010 pukul 20.22

4. Janoko. kabel serial. http:/kbscomputer.com/store/images/SERIALDB25DB9.jpg\& imjrefurl) kamis 5 agustus 2010pukul 22.25

5. Juno. Komponen. http://www.elektroniclab.com/index.php?optio $\underline{\mathrm{n}=\text { comcontent } \& \text { view }=\text { article \&id }=9 \text { :kapasitor }-}$ $\underline{\text { \&catid=6:elkadasar\&Itemid }=7}$ senin, 14 juni 2010

6. Perpustakaan waluyo. basic-of-dioda http://perpustakaanwaluyo.wordpress.com /2008/07/05/ basic- of-dioda/ kamis, 03 juni 2010 pukul 20.33

7. Remaja. Efisiensi Trafo. kbs.jogjakota.go.id/upload/EFISIENSI\%20T RAFO.doc rabu, 14 juli 2010 pukul 20.30

8. Rianto.Penyearah.irianto.staff.gunadarma.ac.i d/Downloads/files/4630/bab2.pdf Kamis, 01 juli 2010 pukul 21.30

9. Rohmad.Resistor.www.capgo.com/Resources/ Measurement/MeasHome/Resistors/ Resistors.html kamis, 03 juni 2010 pukul 20.33

10. Setyobudi.komponenelektronika.http://www.a mpbuildersparts.com selasa, 01 juni 2010 pukul 21.00

11. Sri Widodo, Thomas. 2002. Elektronika Dasar. Jakarta: Salemba Teknika.

12. Susilo.Elektronika.http://www.Wikipedia.com selasa, 15 juni 2010 pukul 18.30

13. Totok Wibowo. Trafo. http://www.edukasi.net $/ \mathrm{mapok} / \mathrm{mp}$ full.php?id=286 senin, 21 juli 2010Pukul 22.30 